\title{
Edukacja w szkołach z polskim językiem nauczania na Zaolziu w opiniach uczniów i ich rodziców
}

Streszczenie: W artykule dokonano skrótowej charakterystyki prawnych aspektów funkcjonowania mniejszości narodowej, przywołano akty tworzące standardy w zakresie ich ochrony wyrażone w prawie międzynarodowym oraz w prawodawstwie czeskim. Polacy mający w Republice Czeskiej status mniejszości narodowej mogą korzystać z przysługujących im praw, zwłaszcza z prawa do edukacji w języku mniejszości, a realizowanym w szkołach z polskim językiem nauczania. Projektując badania dotyczące szkoły, przyjęłam paradygmat funkcjonalno-strukturalny. W tym ujęciu szkoła jest miejscem socjalizacji, w którym następuje reprodukowanie norm, wartości i tradycji. W konstrukcji teoretycznej podjętych rozważań skorzystano także z koncepcji tożsamości wyboru Charlesa Taylora, koncepcji tożsamości i identyfikacji narodowej w ujęciu Antoniny Kłoskowskiej.

Badania z zastosowaniem metody ankiety przeprowadzono wśród rodziców i ich dzieci, uczniów z klas dziewiątych ze szkół podstawowych z polskim językiem nauczania funkcjonujących na Zaolziu. Ich celem było poznanie opinii o edukacji w tych szkołach.

Wyniki badań wskazują, iż dla rodziców uczniów ze szkół z polskim językiem nauczania wybór szkoły dla własnego dziecka jest przejawem polskości, a dla ich dzieci powodem uczęszczania jest możliwość nauki języka polskiego, fakt bycia Polakiem oraz dbałość o zachowanie polskości.

Słowa kluczowe: Republika Czeska, polska mniejszość narodowa, szkoły z polskim językiem nauczania

\section{Wprowadzenie}

Republika Czeska jest jednym z najbardziej jednolitych narodowościowo krajów w Europie. Trudno jest podać liczbę osób deklarujących inną narodowość niż czeską, bowiem w spisie powszechnym z roku 2011 aż 25,3\% obywateli nie zadeklarowało żadnej narodowości. W Statucie Rady ds. Mniejszości 
Narodowych zostało wymienionych 14 narodowości mających w Czechach status mniejszości narodowych: białoruska, bułgarska, chorwacka, niemiecka, polska, romska, rusińska, ruska, grecka, słowacka, serbska, ukraińska, węgierska i wietnamska. Za trzy najliczniejsze mniejszości uznaje się polską ${ }^{1}$, słowacką i ukraińską. Jako czwartą pod tym względem wymienia się mniejszość wietnamską ${ }^{2}$. Jednak tylko polska mniejszość narodowa ma w pełni zorganizowane szkolnictwo we własnym języku narodowym.

Aktualnie w Republice Czeskiej, podobnie jak w innych krajach, trwa spis narodowy. Te dobrowolne deklaracje w rubryce narodowość są ważne nie tylko dla Polaków będących członkami polskiej mniejszości narodowej. Wprawdzie edukacja w języku mniejszości nie jest wprost powiązana ze spisem ludności, jednak liczba osób poczuwających się za Polaków może być ważna tak dla samej mniejszości, jak i dla osób decydujących o podziale środków na finansowanie działalności polskiej mniejszości - jej instytucji, organizacji pozarządowych - w różnych obszarach życia społeczno-kulturalnego.

Na potrzeby niniejszych rozważań przyjęto funkcjonalno-strukturalną teorię szkoły. Szkoła, będąc elementem systemu społecznego, jest - obok rodziny - główną agendą socjalizacji i zapewnia ciągłość wartości, norm kulturowych oraz ciągłość społeczeństwa (Sawisz, 1989, s. 5). Szkoła pełni dwie funkcje: zewnętrzną i wewnętrzną. Pierwsza z funkcji jest narzucona przez społeczeństwo, a w przypadku szkoły z językiem mniejszości oczekiwania wobec niej formułuje także właściwa dla niej mniejszość narodowa. Zatem w szkole młodzi mają możliwość poznania dorobku kulturowego społeczeństwa czeskiego i polskiego oraz dorobku polskiej mniejszości narodowej żyjącej od pokoleń na Zaolziu.

W obrębie funkcji wewnętrznej w szkole są realizowane funkcje edukacyjne, adaptacyjne, kulturowe, ideologiczne, integracyjne, społeczne i inne (Woźniak, 1998, ss. 228-229).

1 Spis ludności z roku 2001 wykazał, że w Republice Czeskiej mieszka 39096 osób narodowości polskiej, co stanowi $0,4 \%$ ogółu ludności. W statystykach podawane są tylko osoby, które zadeklarowały jedną narodowość. Osoby, które wybrały dwie narodowości, na przykład polską i czeską, były policzone w kategorii narodowości czeskiej.

2 W roku 2013 przyznano miejsce w Radzie Rządu ds. Mniejszości Narodowych przedstawicielowi Wietnamczyków, tym samym uznano ich za mniejszość narodową (Szyszlak, 2016). 


\section{Mniejszości narodowe - definicje, regulacje prawne}

Normy prawne dotyczące ochrony mniejszości ujęte są między innymi w dokumentach powstałych w ramach Organizacji Narodów Zjednoczonych, Rady Europy, Unii Europejskiej (Białek, 2008, ss. 43-69). Podczas Zgromadzenia Parlamentarnego Rady Europy w 1993 roku podjęto próbę stworzenia definicji mniejszości narodowych (Art. 1 Rekomendacji nr 1201, 1993). Zgodnie z nią pojęcie mniejszości narodowej miało się odnosić do grupy ludzi w danym państwie, która: przebywa na terytorium tego państwa i posiada jego obywatelstwo; utrzymuje długotrwałe, stałe i trwałe więzi z tym państwem; cechuje się odmiennością etniczną, kulturową, religijną lub językową; jest należycie reprezentowana, jednakże mniejsza liczebnie niż reszta populacji państwa albo regionu tegoż państwa; jest zmotywowana troską o zachowanie jedności, która konstytuuje ich wspólną tożsamość, włącznie z ich tradycją, kulturą, religią i językiem. Z uwagi na fakt, iż dokument nie wszedł w życie do dziś, nadal nie ma powszechnie uznawanej definicji pojęcia mniejszości narodowej. Wiele dokumentów prawa międzynarodowego ${ }^{3}$ dotyczy ochrony praw człowieka lub mniejszości (Białek, 2008). W dokumentach wymienia się najczęściej mniejszości narodowe, etniczne, religijne lub językowe. $\mathrm{Na}$ potrzeby niniejszego opracowania przywołam definicję zapisaną w Instrumencie Inicjatywy Środkowoeuropejskiej Ochrony Praw Mniejszości Narodowych (z 1994 roku). W artykule 1 tego dokumentu zapisano, iż mniejszość narodowa oznacza: „grupę mniejszą liczebnie od pozostałej części ludności w danym Państwie, której członkowie, będący obywatelami danego Państwa, mają etniczne, religijne lub językowe cechy odróżniające je od pozostałej czę-

3 Wymienić należy dokumenty powstałe w ramach Organizacji Narodów Zjednoczonych (m.in. Karta Narodów Zjednoczonych, Powszechna Deklaracja Praw Człowieka, Międzynarodowy pakt praw obywatelskich i politycznych, Deklaracja praw osób należących do mniejszości narodowych lub etnicznych, religijnych i językowych); Rady Europy (Europejska Konwencja o ochronie praw człowieka i podstawowych wolności, Protokół dodatkowy nr 12 do Europejskiej Konwencji o ochronie praw człowieka i podstawowych wolności europejskiej, Konwencja ramowa o ochronie mniejszości narodowych, Europejska karta języków regionalnych lub mniejszościowych); Unii Europejskiej (Traktat o Unii Europejskiej, Traktat o funkcjonowaniu Unii Europejskiej, Karta Praw Podstawowych UE, Rezolucje Parlamentu Europejskiego, Dyrektywa Rady Unii Europejskiej 2000/43/EC wprowadzająca w życie zasadę równego traktowania osób niezależnie od ich pochodzenia rasowego lub etnicznego). 
ści ludności i kierują się wolą zachowania własnej kultury, tradycji, religii lub języka" (Janusz i Bajda, 2000, s. 59). Jest to zapis deklaratywny i pozostawiono poszczególnym państwom dookreślenie tego pojęcia, jak również prawo określenia, które grupy zostaną prawnie uznane za mniejszości narodowe.

W czeskim prawie dosyć obszernie zdefiniowano mniejszości narodowe w Ustawie o prawach członków mniejszości narodowych z dnia 10 lipca 2001 roku (Zákon o právech príslušníkư..., 2001). W \$ 2. ust. 1. zapisano ${ }^{4}$, iż mniejszość narodowa to wspólnota obywateli Republiki Czeskiej mieszkających w obecnej Republice Czeskiej, różniących się od innych obywateli zwykle wspólnym pochodzeniem etnicznym, językiem, kulturą i tradycjami, którzy tworzą liczebnie mniejszość obywateli i jednocześnie przejawiają wolę bycia uznanym za mniejszość narodową w celu wspólnych działań na rzecz zachowania i rozwoju własnej tożsamości, języka, kultury i jednocześnie w celu wyrażenia i ochrony interesów ich wspólnoty, która została historycznie wytworzona.

Z kolei zgodnie z ust. 2 tego samego paragrafu: Członkiem mniejszości narodowej jest obywatel Republiki Czeskiej, który deklaruje inną narodowości niż czeska i wyraża chęć bycia uznawanym za członka mniejszości narodowej wraz z innymi osobami deklarującymi się jako osoby tej samej narodowości (Zákon o právech príslušníků ..., 2001). W ustawie zaakcentowano zatem prawo każdej osoby do swobodnego decydowania o własnej narodowości i przynależności do mniejszości narodowej. Zatem można przywołać wypowiedź Janusza Kochanowskiego (2006), którego zdaniem narodowość jest stanem świadomości każdego człowieka i wynikającą z tego stanu identyfikacją z określoną grupą etniczną. Zatem bardzo ważną kwestią jest edukacja w języku ojczystym oraz zachowanie tożsamości narodowej.

\section{Edukacja w języku mniejszości narodowej w Republice Czeskiej}

W przypadku osób należących do mniejszości narodowej o narodowości dziecka decydują jego rodzice i to oni podejmują decyzję o wyborze przedszkola i szkoły podstawowej dla swojego dziecka.

Osoby będące członkami mniejszości narodowych w Republice Czeskiej prawo do edukacji w języku narodowym mają zagwarantowane w Konstytucji oraz w aktach niższej rangi, między innymi w Ustawie o prawach człon-

4 Cytowane w artykule fragmenty dokumentów prawnych podaję w tłumaczeniu własnym. 
ków mniejszości narodowych w RC (Zákon o právech příslušníků..., 2001) oraz w ustawie o edukacji w przedszkolu, szkole podstawowej i średniej oraz wyższej szkole zawodowej z 2004 roku. W paragrafie 13 uwzględniono możliwość kształcenia w języku mniejszości narodowej, natomiast w $\mathbb{S} 14$. określono warunki, jakie powinny być spełnione, aby utworzyć klasę. W dokumencie określono minimalną liczbę dzieci w przedszkolach i szkołach podstawowych, a w szkole średniej dopuszczono możliwość utworzenia klasy z językiem nauczania mniejszości w sytuacji, gdy zbierze się co najmniej 15 uczniów, członków danej mniejszości.

Ważnym dokumentem dla polskiej mniejszości narodowej jest dwustronna Umowa między Rządem RP a Rządem Republiki Czeskiej o współpracy w dziedzinie kultury, szkolnictwa i nauki (Umowa między Rzadem RP..., 2004). W artykule 11 zapisano, iż w obu krajach zapewnia się osobom należącym do mniejszości narodowych warunki sprzyjające zachowaniu, rozwojowi i wyrażaniu ich tożsamości narodowej, religijnej, kulturowej i językowej w ramach przepisów obowiązujących w danym kraju. W odniesieniu do polskiego szkolnictwa narodowościowego w Republice Czeskiej oznacza to, iż funkcjonuje ono zgodnie z czeskimi regulacjami prawnymi.

W Republice Czeskiej centralnym organem zajmującym się szkolnictwem na wszystkich poziomach - od przedszkolna do szkół wyższych - jest Ministerstwo ds. Edukacji, Młodzieży i Sportu (Ministerstvo školství, mládeže a tělovýchovy - MSMT) i odpowiada ono za opracowywanie polityk edukacyjnych, młodzieżowych i sportowych oraz współpracę międzynarodową w tych dziedzinach. Funkcjonowanie szkolnictwa, warunki realizacji nauki, właściwych organów instytucji rządowych i samorządowych związanych ze szkolnictwem oraz prawa i obowiązki poszczególnych osób fizycznych i prawnych określa ustawa o edukacji (Zákon o předškolním..., 2004).

Ministerstwo prowadzi program (Programy na podporu...) wspierający edukację w językach mniejszości i każdego roku ogłasza nabór wniosków o dotacje na wsparcie działalności edukacyjnej. Celem programu jest wspieranie tworzenia warunków do realizacji polityki państwa w zakresie edukacji w językach mniejszości narodowych, program wspierania edukacji dzieci i uczniów z różnych środowisk językowych i kulturowych, wsparcie projektów wielokulturowej edukacji dzieci, uczniów i młodzieży do 26. roku życia, poznawanie historii i kultury innych narodów, prowadzące do wzajemnej tolerancji i walki z rasizmem i ksenofobią.

Organizacją szkolnictwa w języku swojej narodowości jest zainteresowana tylko polska mniejszość narodowa i tym samym zapewnia wykształce- 
nie w języku polskim w kompletnym cyklu edukacyjnym od przedszkola do szkoły średniej.

Szkolnictwo z polskim językiem nauczania w Republice Czeskiej funkcjonuje w dwóch powiatach: karwińskim i frydecko-misteckim. Na sieć szkolnictwa na Zaolziu składa się w powiecie karwińskim 12 przedszkoli (856 przedszkolaków ${ }^{5}$ ) oraz w powiecie frydecko-misteckim 20 przedszkoli (496 przedszkolaków). Ich zadaniem jest edukacja obywateli czeskich deklarujących polską narodowość zgodnie z programami edukacyjnymi w języku polskim, zgodnie z Ramowym programem nauczania dla szkół z polskim językiem nauczania. Funkcjonowanie polskiego szkolnictwa narodowościowego wspiera Centrum Pedagogiczne dla Polskiego Szkolnictwa Narodowościowego, mające siedzibę w Czeskim Cieszynie. Centrum prowadzi nadzór metodyczny oraz organizuje doskonalenie zawodowe dla nauczycieli pracujących w przedszkolach i szkołach (Grabowska i Ogrodzka-Mazur, 2010).

W zakresie szkół podstawowych funkcjonują dwa rodzaje szkół: małoklasowe (I-V) i pełnoklasowe (I-IX). Szczegółowe dane przedstawiono w tabeli 1.

Tabela 1. Liczba klas i uczniów w szkołach podstawowych z polskim językiem nauczania w roku szkolnym 2020-2021

\begin{tabular}{|l|c|c|c|c|c|c|}
\hline \multirow{2}{*}{ Kategorie } & \multicolumn{2}{|c|}{ Powiat Karwina } & \multicolumn{2}{c|}{$\begin{array}{c}\text { Powiat } \\
\text { Frydek-Mistek }\end{array}$} & \multicolumn{2}{c|}{ Ogółem } \\
\cline { 2 - 8 } & $\begin{array}{c}\text { Liczba } \\
\text { klas }\end{array}$ & $\begin{array}{c}\text { Liczba } \\
\text { uczniów }\end{array}$ & $\begin{array}{c}\text { Liczba } \\
\text { klas }\end{array}$ & $\begin{array}{c}\text { Liczba } \\
\text { uczniów }\end{array}$ & $\begin{array}{c}\text { Liczba } \\
\text { klas }\end{array}$ & $\begin{array}{c}\text { Liczba } \\
\text { uczniów }\end{array}$ \\
\hline Szkoły podstawowe z klasami I-V & 10 & 118 & 22 & 234 & 32 & 352 \\
\hline Szkoły podstawowe z klasami I-IX & 50 & 775 & 57 & 946 & 107 & 1721 \\
\hline Ogółem & 60 & 893 & 79 & 1180 & 139 & 2073 \\
\hline
\end{tabular}

Źródło: Placówki edukacyjne. Statystyka. https://www.pctesin.cz/files/download/741-statystyka-2020-2021-pl.pdf (16.03.2021).

Wprawdzie w tabeli zawarto dane za rok szkolny 2020-2021, to jednak analiza danych archiwalnych dotyczących liczby szkól, klas i uczniów z polskim językiem nauczania z ostatnich kilkunastu lat pozwala zauważyć, że dzięki staraniom polskiej mniejszości narodowej została zahamowana tendencja spadkowa i można dostrzec tylko delikatne zmiany w liczbie uczniów na poszczególnych etapach edukacji.

\footnotetext{
5 Dane za rok szkolny 2020-2021.
} 


\section{Założenia metodologiczne badań własnych}

Badania zostały zrealizowane na terenie czeskiego Śląska Cieszyńskiego, na Zaolziu. Przedmiotem badań uczyniono opinie uczniów i ich rodziców o szkołach z polskim językiem nauczania. Celem badań było poznanie deklaracji dotyczących poczucia tożsamości uczniów ze szkół z polskim językiem nauczania i ich rodziców oraz ich doświadczeń związanych z uczęszczaniem do placówek edukacyjnych z polskim językiem nauczania.

W pytaniu dotyczącym poczucia tożsamości zaproponowano do wyboru tylko kategorię narodową (Czech/Czeszka, Polak/Polka) i obywatelską. W przypadku Czechów obie kategorie się pokrywają, a w przypadku osób deklarujących polską narodowość bycie Cechem/Czeszką ma wymiar identyfikacji z kulturą kraju zamieszkania. Celowo pominięto kategorię regionalną - poczucie bycia Zaolzianinem/Zaolzianką - oraz kategorie ponadnarodowe - bycie Europejczykiem i Obywatelem świata. W badaniach interesowały mnie między innymi opinie rodziców i ich dzieci o funkcjonowaniu szkół z polskim językiem nauczania, motywy ich wyboru, a także powody kontynuowania nauki w szkołach czeskich.

Założono, że uczniowie kończący naukę w szkole podstawowej mają już plany edukacyjne związane $\mathrm{z}$ kontynuowaniem nauki w języku polskim lub czeskim. Dobór grupy badanej był celowy. Badania z zastosowaniem metody ankiety audytoryjnej przeprowadzono wśród wszystkich uczniów z dziewiątych klas i ich rodziców wiosną, w roku szkolnym 2017-2018, w dziewięciu (na dziesięć) pełnoklasowych szkołach podstawowych w powiecie karwińskim i frydecko-misteckim. Do dalszych analiz zakwalifikowanych zostało 161 kompletnie wypełnionych kwestionariuszy ankiety przez uczniów i 48 wypełnionych przez rodziców.

\section{Opinie uczniów i ich rodziców o edukacji w szkołach z polskim językiem nauczania na Zaolziu - omówienie wyników badań}

Członkowie mniejszości narodowych mają możliwość mniej lub bardziej równorzędnego funkcjonowania we własnej grupie mniejszościowej, jak i w grupie większościowej. Mają zatem możliwość socjalizacji i kulturalizacji w dwóch kodach kulturowych. Zdaniem Antoniny Kłoskowskiej człowiek może w trakcie swojego życia identyfikować się z wieloma grupami i w róż- 
nych okresach życia przejawiać: uniwalencję, poliwalencję, biwalencję lub ambiwalencję. Osoby należące do mniejszości narodowej w sposób naturalny uczestniczą w życiu grupy narodowej (mniejszościowych) i większościowej (obywatelskiej), mogą zatem odczuwać związek z wieloma kulturami i na bazie poczucia wspólnoty z własną grupą budować poczucie wspólnoty z innymi grupami, a jak zauważa A. Kłoskowska, kolejno odczuwane więzi nie redukują wcześniejszych (Kłoskowska, 1996, s. 162).

Koncepcją tożsamości uwzględniającą punkt widzenia podmiotów i subiektywne znaczenia, jakie nadają one swym działaniom, jest koncepcja tożsamości wyboru Charlesa Taylora (1995). Człowiek - zdaniem autora - nie tyle musi się odnajdywać w ustanowionym horyzoncie moralnym świata życia, ale być twórcą własnej tożsamości, dzięki czemu staje się ona dla niego czymś osobistym. Fakt, że każdy człowiek jest usytuowany w jakiejś społeczności, oznacza, że jego tożsamość jest rezultatem jego relacji z tą społecznością. „Żeby tożsamość była moja, muszę ją zaakceptować, co przynajmniej w teorii otwiera pole do negocjacji z moim środowiskiem, moją historią, moim przeznaczeniem” (Taylor, 1995, s. 12).

Większość badanych rodziców i uczniów zadeklarowała dwuwymiarowe poczucie tożsamości, przy czym większość identyfikuje się z narodowością, ale wymiar obywatelski jest obecny - zwłaszcza u uczniów. Uczniowie częściej niż ich rodzice deklarują biwalencję narodową, tak z przewagą polską (17,7\% R, 39,8\% U), jak i czeską (9,6\% R, 19,3\% U). Rodzice natomiast częściej mają w równej mierze zintegrowane oba wymiary identyfikacji - czeski i polski. Może to być związane z większą liczbą doświadczeń bikulturowych. Mają więcej sposobności, by wchodzić w bliższe relacje podmiotowe z Czechami, na przykład w środowisku pracy.

Tabela 2. Poczucie identyfikacji rodziców i uczniów (dane podano w procentach)

\begin{tabular}{|l|c|c|}
\hline \multicolumn{1}{|c|}{ Kategorie } & Rodzice & Uczniowie \\
\hline Czuję się Polakiem/Polką & 28,0 & 24,2 \\
\hline Czuję się Polakiem/Polką i Czechem/Czeszką, ale raczej Polakiem/Polką & 17,7 & 39,8 \\
\hline Czuję się Polakiem/Polką i Czechem/Czeszką w jednakowym stopniu & 28,0 & 11,2 \\
\hline Czuję się Polakiem/Polką i Czechem/Czeszką, ale raczej Czechem/Czeszką & 9,6 & 19,3 \\
\hline Czuję się Czechem/Czeszką & 16,7 & 2,5 \\
\hline Czuję się kimś innym & 0 & 3,0 \\
\hline
\end{tabular}

Źródło: badania własne.

Większa liczba rodziców - niż ich dzieci - deklarująca narodowość czeską może być związana $\mathrm{z}$ faktem, iż w małżeństwach mieszanych narodowościo- 
wo narodowość dziecku wybierają rodzice, często na zasadzie kompromisu. Za tą idzie kolejna decyzja o posłaniu dziecka do placówki edukacyjnej z polskim językiem nauczania. Podobna liczba rodziców i uczniów deklaruje uniwalencję narodową polską (28\% R i 24,2\% U).

\section{Doświadczenia badanych rodziców i ich dzieci związane z placówkami edukacyjnymi z polskim językiem nauczania}

Jak już pisałam wcześniej, decyzje o wyborze przedszkola i szkoły podstawowej podejmują rodzice. Większość badanych rodziców swoje dzieci skierowało do placówek narodowościowych. Ponad połowa ich dzieci kontynuowała naukę w szkoła średnich, a prawie $17 \%$ wybrało studia w Polsce. Nauka w szkole średniej - w Polskim Gimnazjum im. Juliusza Słowackiego lub w Akademii Handlowej, obie szkoły w Czeskim Cieszynie - przygotowuje do studiów wyższych zarówno w Polsce (maturzyści zdają maturę z języka polskiego), jak i w Czechach.

Tabela 3. Uczęszczanie do placówek z polskim językiem nauczania badanych uczniów i dzieci badanych rodziców (dane podano w procentach)

\begin{tabular}{|l|c|c|}
\hline \multicolumn{1}{|c|}{ Kategorie } & Dzieci badanych rodziców & Uczniowie \\
\hline Przedszkole & 91,7 & 87,0 \\
\hline Szkoła podstawowa & 91,7 & 100,0 \\
\hline Szkoła średnia & 58,3 & - \\
\hline Studia w Polsce & 16,7 & - \\
\hline
\end{tabular}

Źródło: badania własne.

Uczęszczanie przez młodych członków mniejszości narodowej do szkoły $\mathrm{z}$ językiem danej narodowości jest istotne w kontekście jej dalszego trwania i rozwoju - tak szkoły, jak i grupy mniejszościowej. Pomimo tego, iż w szkole z polskim językiem nauczania realizowana jest czeska podstawa programowa, to dla członków mniejszości narodowej najważniejsza jest funkcja etniczna. Przejawia się ona w dążeniu do zachowania ciągłości kulturowej pomiędzy kolejnymi pokoleniami danej narodowości.

W szkole sfera narodowa i obywatelska nakładają się na siebie. To, co różni szkołę czeską od polskiej, to położenie akcentów na poszczególne elementy. W szkole z polskim językiem nauczania działania w obrębie sfery narodowej mają na celu pomoc w kształtowaniu polskiej tożsamości narodowej, wychowanie w duchu kultury swojej grupy mniejszościowej, przekazie wartości, norm, zasad funkcjonowania, a zwłaszcza na nauce języka polskiego. Możemy 
zatem mówić o szeroko rozumianej kulturalizacji do polskości. Równolegle - aczkolwiek z mniejszym akcentem - prowadzona jest socjalizacja w sferze obywatelskiej, zmierzająca do wyposażenia w kompetencje do funkcjonowania w kraju zamieszkania jako jego obywatel. Szkoła narodowościowa - jak wskazują dotychczasowe wyniki badań prowadzone od prawie trzech dziesięcioleci przez zespół badawczy pod kierunkiem Tadeusza Lewowickiego ${ }^{6}$ - wprowadza swoich uczniów między innymi w pluralizm kulturowy, w świat wartości uniwersalnych, kształtuje postawy otwartości i tolerancji.

\section{Motywy wyboru szkoły średniej z polskim językiem nauczania}

Wybór szkoły przez rodziców dla swoich dzieci jest najczęściej świadomy i celowy. Na decyzję o podjęciu dalszej nauki w szkole z polskim językiem wpływa wiele różnych motywów i często jest to decyzja dotycząca wyboru dalszej drogi życiowej. Jest ona dobrowolna i indywidualna, jednak ważna z punktu widzenia grupy mniejszościowej.

Nauka w szkole średniej umożliwia nie tylko zdanie matury i zdobycie średniego wykształcenia, ale również daje możliwość kontynuowania nauki w czeskich i polskich uczelniach wyższych. W przypadku młodzieży zaolziańskiej są to, jak pisałam już wcześniej, dwie szkoły średnie, liceum ogólnokształcące i technikum.

Rodziców w badaniach ankietowych zapytano o powody wyboru przez nich i ich dzieci szkoły podstawowej i średniej, natomiast $\mathrm{w}$ ankiecie dla uczniów umieszczono analogiczne pytanie, jednak dotyczące jedynie szkoły średniej. Brzmienie pytań było zbliżone w obu kwestionariuszach. Poznajmy zatem motywy wyboru szkoły narodowościowej uczniów z tych szkół i rodziców uczniów.

Jak wskazują wyniki badań zawarte w tabeli 4, rodzice uważają, że to oni (75\%) będą decydować o wyborze szkoły średniej dla swoich dzieci. Odmienne zdanie w tej kwestii ma większość badanych uczniów, bowiem tylko 23,6\% napisało, że będzie kierować się wolą rodziców. Mniej niż jedna trzecia rodziców (22,9\%) deklaruje wziąć pod uwagę wolę dziecka, a 41\% uczniów jest przekonanych, że to oni będą decydować o swoich wyborach edukacyjnych. I chociaż zdania badanych rodziców i ich dzieci nie są zbieżne w tej kwestii,

6 Pod kierunkiem prof. dra hab. T. Lewowickiego ukazuje się seria „Edukacja Międzykulturowa" licząca aktualnie 85 tomów. 
to najistotniejszym jest fakt, że większość badanych uczniów $(80,1 \%)$ deklaruje chęć kontynuacji nauki w średnich szkołach z polskim językiem nauczania.

Tabela 4. Motywy wyboru szkoły średniej z polskim językiem nauczania deklarowane przez rodziców i ich dzieci (dane podano w procentach)

\begin{tabular}{|l|c|c|}
\hline \multicolumn{1}{|c|}{ Kategorie } & Rodzice & Uczniowie \\
\hline Inicjatywa/wola dziecka & 22,9 & 41,0 \\
\hline Możliwość nauki języków & 66,7 & 43,5 \\
\hline Kontakt z polskimi rówieśnikami & 41,7 & 46,6 \\
\hline Przygotowanie do życia w świecie zróżnicowanym kulturowo & $\mathbf{4 1 , 7}$ & 16,8 \\
\hline Chęć poznania języka i kultury przodków & 33,3 & 32,3 \\
\hline Chęć studiowania w Polsce & 18,8 & 29,2 \\
\hline Zainteresowania & 16,7 & $\mathbf{4 7 , 2}$ \\
\hline Wola rodziców & 75,0 & 23,6 \\
\hline Zdanie matury z języka polskiego & 35,4 & 30,4 \\
\hline Zdanie matury z języka czeskiego & 16,7 & 20,5 \\
\hline Nie wiem & 0 & 6,2 \\
\hline Inne & 18,8 & 9,3 \\
\hline
\end{tabular}

Legenda: dane nie sumują się do 100\%, ponieważ badani mogli wskazać więcej niż jeden motyw. Źródło: badania własne.

Uczniowie, wybierając szkołę średnią z polskim językiem nauczania, będą kierować się między innymi możliwością nauki języków (66,7\%), własnymi zainteresowaniami $(47,2 \%)$, kontaktem z polskimi rówieśnikami $(46,6 \%)$. Czynniki te możemy uznać za składowe motywacji wewnętrznej, czego wyrazem jest odczuwanie zainteresowania i zadowolenia ze swojej decyzji. I z tego punktu widzenia przekonanie młodzieży, że to oni decydują o dalszej drodze edukacyjnej, jest istotne i ważne.

Prawie 20\% badanych uczniów planuje kontynuować naukę w czeskiej szkole. Zapytano uczniów i ich rodziców o opinie na temat powodów wybierania przez młodzież polskiej narodowości szkół czeskich.

Tabela 5. Powody kontynuowania nauki w szkołach czeskich w opiniach rodziców i uczniów (dane podano w procentach)

\begin{tabular}{|l|c|c|}
\hline \multicolumn{1}{|c|}{ Kategorie } & Rodzice & Uczniowie \\
\hline Język nauczania nie ma znaczenia & 22,9 & 19,9 \\
\hline Brak średnich szkół z językiem polskim & 43,8 & 41,6 \\
\hline
\end{tabular}




\begin{tabular}{|l|r|c|}
\hline Daleki dojazd do szkoły z polskim językiem & 6,3 & 46,0 \\
\hline Chęć studiowania w Republice Czeskiej & 8,3 & 26,1 \\
\hline Inne & 10,4 & 11,8 \\
\hline
\end{tabular}

Źródło: badania własne.

Badania wskazują na obiektywne przeszkody utrudniające dotarcie do szkół z polskim językiem, ich małą liczbę, daleki dojazd, bowiem obie szkoły są zlokalizowane w Cieszynie.

Jedna czwarta badanych uczniów wie, że chce studiować w Czechach i wybór czeskiej szkoły średniej jest wyborem języka dalszej edukacji. Spora część badanych rodziców i ich dzieci żywi przekonanie, iż język nauczania nie ma znaczenia. Zapominają jednak o dodatkowych funkcjach szkoły mniejszościowej, zwłaszcza funkcji etnicznej.

Powyższe wyniki pozwalają sformułować tezę, iż w motywach deklarowanych przez uczniów i ich rodziców można dostrzec pragnienie zaspakajania potrzeb społecznych (potrzeby przynależności, akceptacji, szacunku), potrzeb zaspakajanych poprzez przynależność do mniejszości narodowej.

\section{Opinie uczniów i ich rodziców o powinności polskiej młodzieży na Zaolziu wybierania szkół z polskim językiem nauczania}

Pytanie o powody wyboru szkoły średniej przez ucznia i jego rodziców miało wymiar indywidualny. W pytaniu o powinności młodzieży polskiej wskazać można na wymiar społeczny takiej decyzji.

Rodzice wskazywali tylko pozytywne uzasadnienia wybierania szkół z polskim językiem nauczania i wymienili średnio po 2,35 powodów. Dorośli najczęściej wybierali potrzebę zachowania polskości (75\%), fakt bycia Polakami (50\%), możliwość lepszego poznania Polski $(29,2 \%)$ oraz oznakę patriotyzmu $(27,1 \%)$.

Uczniowie w wyrażaniu swoich opinii uwzględnili zapewne swoje trudności związane z dotarciem do szkoły, bowiem u nich pojawiły się argumenty o braku takiej powinności (0,72 wskazania na osobę) i w uzasadnieniu wymieniali odległość od tych szkół i ich małą liczbę. Tu również pojawiła się opinia o podobnym wykształceniu, jakie można zdobyć w szkole czeskiej i w szkole z polskim językiem. 
Tabela 5. Opinie rodziców i uczniów o powinności polskiej młodzieży na Zaolziu wybierania szkół z polskim językiem nauczania (dane podano w procentach)

\begin{tabular}{|c|c|c|c|}
\hline & Kategorie & Rodzice & Uczniowie \\
\hline \multirow{6}{*}{ है } & Ważne dla zachowania polskości & 75,0 & 41,6 \\
\hline & Oznaka patriotyzmu & 27,1 & 28,0 \\
\hline & Język polski jest językiem ojczystym & 1,6 & 41,0 \\
\hline & Jesteśmy Polakami & 50,0 & 40,4 \\
\hline & Żeby lepiej poznać Polskę & 29,2 & 30,4 \\
\hline & Inne & 4,2 & 3,1 \\
\hline \multirow{4}{*}{$\stackrel{\vartheta}{z}$} & Polskich szkół jest za mało & 0 & 18,6 \\
\hline & Do polskich szkół jest daleko & 0 & 22,4 \\
\hline & Szkoły czeskie dają takie samo wykształcenie & 0 & 25,5 \\
\hline & Inne & 0 & 5,6 \\
\hline
\end{tabular}

Źródło: badania własne.

Większość uczniów dostrzegła potrzebę wybierania szkoły, w której można uczyć się w języku własnej mniejszości i uważają to za ważne dla zachowania polskości (41,6\%), fakt bycia Polakiem (40,4\%) i argument pominięty przez ich rodziców - język polski jest ich językiem ojczystym (41\%). Uczniowie podawali średnio po 1,84 powody.

W wyrażonych opiniach o potrzebie pobierania nauki w języku polskim spotykają się oczekiwania zwłaszcza dorosłego i starszego pokolenia Polaków z Zaolzia, bowiem często szkoła jest przez nich postrzegana jako „strażnik kultury" (Lewowicki, 2010, s. 16). Szkoły narodowościowe - z racji swej specyfiki - realizują dodatkowe zadania wyznaczone przez własną mniejszość narodową.

Na powyższe wyniki badań można spojrzeć przez pryzmat teorii oczekiwań. Wprawdzie została ona opracowana na potrzeby organizacji i motywowania do pracy, jednak może być wykorzystana w interpretacji tych wyników badań. W ujęciu Victora H. Vrooma (1995) zachowanie jest określone przez połączenie sił tkwiących w jednostce i w otoczeniu. Ludzie wybierają określone zachowania spośród różnych możliwości, a podejmując decyzje, kierują się licznymi czynnikami, tak aby uzyskać swoje cele. Indywidualne zachowanie, decyzje każdego człowieka - w tym przypadku rodziców i ich dzieci - determinowane są nie tylko przez ich potrzeby/oczekiwania, ale także przez otoczenie, w którym funkcjonują, czyli innych członków polskiej mniejszości narodowej. Decyzja o wyborze dla dziecka przedszkola/szkoły z polskim językiem nauczania bywa traktowana jako zewnętrzny przejaw i wyraz polskości. W małych społecznościach, gdzie wszyscy się znają, decy- 
zje edukacyjne bywają szeroko komentowane. Zatem w planowaniu ścieżki edukacyjnej dziecka rodzice mniej kierują się zainteresowaniami dziecka, a bardziej społecznymi potrzebami swojej grupy mniejszościowej.

\section{Konkluzje}

Interakcje i stosunki społeczne na Zaolziu między społeczeństwem większościowym i polską mniejszością narodową kształtowały się przez dziesięciolecia i aktualnie możemy mówić o zaniku konfliktów (Grabowska, 2012). Polacy na Zaolziu są zwartą grupą mniejszościową, skonsolidowaną przez lata społecznością, dającą swoim członkom „oparcie”, również instytucjonalne (Grabowska, 2009). Mniejszość jako grupa zaspakaja poczucie przynależności, daje świadomość posiadania swojego miejsca w świecie, miejsca w historii regionu, narodu. Członek mniejszości narodowej, „przechodząc” proces kulturalizacji, nie jest sam, ma swoją grupę odniesienia, grupę osób będących w takiej samej jak on sytuacji, ma przodków, którzy też funkcjonowali w środowisku zróżnicowanym kulturowo. Doświadcza wchodzenia w kulturę kraju zamieszkania, ale ciągle ma poczucie stałości, ciągłości, ma poczucie przynależności do większej grupy etnicznej, może się z nią utożsamiać, jest jej częścią.

Zaolziańska społeczność ma możliwość swobodnego manifestowania własnej narodowości, własnej inności, odrębności. Funkcjonujący współcześnie na pograniczu polsko-czeskim przede wszystkim interakcyjny i asymilacyjny typ współżycia międzyetnicznego (Grabowska, 2010) modyfikuje w znacznym zakresie utrwalone wcześniej stereotypy oraz uprzedzenia, jak również sposoby percepcji obcych grup etnicznych i narodów.

Nauka w szkole z polskim językiem nauczania jest nie tylko realizacją czeskiej podstawy programowej w języku przodków, ale spełnia ona istotne funkcje dla polskiej mniejszości narodowej. Uczniowie poza przyswajaniem treści przewidzianych w programie kształcenia uczestniczą w życiu szkoły skierowanym na kształtowanie i podtrzymywanie polskiej świadomości narodowej oraz polskiej tożsamości. Członkowie mniejszości narodowej, przebywając stale w obszarze oddziaływania dwóch kultur, są predestynowani do bycia osobami dwukulturowymi. Jednak to edukacja w szkole z polskim nauczaniem służy podtrzymaniu i wzmacnianiu poczucia tożsamości oraz kształtowaniu świadomości własnego - polskiego - dziedzictwa kulturowego. 


\section{Bibliografia}

Art. 1 Rekomendacji nr 1201. 1993. Zgromadzenia Parlamentarnego Rady Europy, 44 sesja, 22 posiedzenie, 1 lutego 1993.

Białek, T. 2008. Międzynarodowe standardy ochrony praw mniejszości narodowych $i$ ich realizacja na przyktadzie Białorusi, Litwy i Ukrainy. Warszawa: Wydawnictwo Naukowe Scholar.

Grabowska, B. 2009. Kapitał społeczny i kulturowy grupy mniejszościowejna przykładzie polskiej mniejszości narodowej na Zaolziu. W: Lewowicki, T., Szczurek-Boruta, A. i Grabowska, B. red. Społeczne uwarunkowania edukacji międzykulturowej. Problemy praktyki oświatowej. Cieszyn - Warszawa - Toruń: Wydział Etnologii i Nauk o Edukacji Uniwersytetu Śląskiego, Wyższa Szkoła Pedagogiczna ZNP w Warszawie, Wydawnictwo Adam Marszałek, ss. 307-325.

Grabowska, B. 2012. Pojednanie i jego zagrożenia na pograniczu polsko-czeskim. W: Kurczewski, J. red. Socjologia pojednania. Kraków: Zakład Wydawniczy „Nomos”, ss. 111-125.

Grabowska, B. 2010. Tożsamość narodowa młodzieży na Śląsku Cieszyńskim. W: Rusek, H., Pieńczak, A. i Szczyrbowski, J. red. Dziedzictwo kulturowe jako klucz do tożsamości pogranicza polsko-czeskiego na Śląsu Cieszyńskim. Kulturní dèdictví jako klíč k identitě česko-polského pohraničí na Těšinském Slezsku. Cieszyn - Katowice - Brno: Bibliotheca Ethnologiae Europae Centralis, ss. 106-119.

Grabowska, B. i Ogrodzka-Mazur, E. 2010. Stan, problemy i perspektywy szkolnictwa z polskim językiem nauczania w Republice Czeskiej. W: Lewowicki, T., Nikitorowicz, J. i Szczurek-Boruta, A. red. Szkolnictwo z polskim językiem nauczania w państwach europejskich - stan, problemy i perspektywy. Warszawa: Uniwersytet w Białymstoku, Uniwersytet Śląski w Katowicach, Wyższa Szkoła Pedagogiczna ZNP, ss. 185-233.

Griffin, R.W. 1996. Podstawy zarzadzania organizacjami. Warszawa: Wydawnictwo Naukowe PWN.

Janusz, G. i Bajda, P. 2000. Prawa mniejszości narodowych. Standardy europejskie. Warszawa: Stowarzyszenie „Wspólnota Polska”.

Kłoskowska, A. 1996. Kultury narodowe u korzeni. Warszawa: Wydawnictwo Naukowe PWN.

Kochanowski, J. 2006. Referat wygłoszony podczas konferencji Prawa mniejszości narodowych i etnicznych $w$ praktyce. Warszawa, 28.06.2006. Za: Krasnowolski, A. 2011. Prawa mniejszości narodowych i mniejszości et- 
nicznych w prawie międzynarodowym i polskim. Opracowania tematyczne OT-599. Warszawa: Kancelaria Senatu.

Placówki edukacyjne. Statystyka. https://www.pctesin.cz/files/download/ 741-statystyka-2020-2021-pl.pdf (16.03.2021).

Programy na podporu vzdělávání v jazycích národnostních menšin. https:// www.msmt.cz/vzdelavani/zakladni-vzdelavani/programy-na-podporu-vzdelavani-v-jazycich-narodnostnich-mensin-a-multikulturni-vychovy (15.02.2021).

Sawisz, A. 1989. Szkoła a system społeczny. Wokót problematyki „nowej socjologii oświaty". Warszawa: WSiP.

Szyszlak, K. 2016. Wietnamczycy w Republice Czeskiej. Między izolacją a integracją. Wschodnioznawstwo. 10, ss. 163-184.

Taylor, Ch. 1995. Źródła współczesnej tożsamości. W: Michalski, K. red. Tożsamość w czasach zmiany. Rozmowy w Castel Gandolfo. Kraków: Wydawnictwo Znak, ss. 9-14.

Umowa między Rzadem RP a Rzadem Rep. Czeskiej o wspótpracy w dziedzinie kultury, szkolnictwa i nauki. https://traktaty.msz.gov.pl/umowa-1. (15.02.2021).

Vroom, V.H. 1995. Work and Motivation. San Francisco: Jossey-Boss Publishers.

Woźniak, R.B. 1998. Zarys socjologii edukacji i zachowań społecznych. Koszalin: Wydawnictwa uczelniane Bałtyckiej Wyższej Szkoły Humanistycznej. Zákon o předškolnim, základnim, střednim, vyšším odborném a jiném vzdělávání (školský zákon). Zákon č. 561/2004 Sb. https://www.zakonyprolidi.cz/cs/2004-561 (16.03.2021).

Zákon o právech př́slušníků národnostních menšin a o změně některých zákonů. Zákon č. 273/2001 Sb. https://www.zakonyprolidi.cz/cs/2001273 (16.03.2021).

Zimbardo, Ph., Johnson, R. i McCann, V. 2010. Psychologia kluczowe koncepcje. Warszawa: Wydawnictwo Naukowe PWN.

https://www.gympol.cz.

https://vdb.czso.cz/vdbvo2/faces/en/index.jsf?page=vystup=-objekt\&z=T\&fTABULKA\& katalog=30715\&pvo=OTCR111\&v=v122_null_null_null. 


\title{
Education in schools with Polish as the teaching language in Zaol- zie in the opinions of learners and their parents
}

\begin{abstract}
Due to the status of a national minority, Poles in the Czech Republic can make use of the rights granted to them. In this study, the legal aspects of the functioning of the national minority were briefly characterized and the acts were addressed which form the standards concerning the protection of these rights both in the international and Czech law. The research based on the application of the questionnaire method was conducted among the parents and children the learners from the ninth class of primary schools with Polish as the teaching language in Zaolzie. This was aimed at finding out the opinions on education in schools teaching in Polish.

The research results show that for the parents of learners educated in schools with Polish as the teaching language the choice of school for their child is a manifestation of their Polishness, whereas the reasons why their children attend these schools is the possibility to learn Polish, the fact of being a Pole and the care for preserving their Polishness.
\end{abstract}

Keywords: Czech Republic, Polish national minority, schools with Polish as the teaching language 